Int. J. Speleol. 19 (1990): 51-66

\title{
Two new Niphargus species (Amphipoda) from caves in Yugoslavia
}

\author{
Gordan Karaman* and Boris Sket**
}

\begin{abstract}
SUMMARY
Niphargus numerus sp. n. from the Čavlinska pećina near Obrovac (Dalmacija) and $N$. factor sp. $\mathrm{n}$. from Vjetrenica (Hercegovina) are described. Both new species from Yugoslav caves belong to the $N$. transitivus aggregate of species.
\end{abstract}

\section{INTRODUCTION}

During last 140 years, numerous members of the predominantly subterranean genus Niphargus Schioedte 1849 have been discovered and described in Yugoslavia by foreign and native scientists (cf. G. Karaman, 1974, 1983), totalling at the moment over 110 taxa. Although many of these taxa deserve a critical reexamination of their taxonomical value, it is evident that caves and interstitial waters of the country are extremely rich in species of this diverse genus.

In this paper we describe just two of a number of still undescribed species. Both were found in the comparatively well studied karstic regions of Croatia and Hercegovina respectively. It is interesting to note that the well known and repeatedly investigated cave Vjetrenica in Popovo polje, the home of a rich fauna, still harbors species undescribed till now.

Both species belong to the $N$. transitivus aggregate of species (cf. Sket, 1971; Sket \& Notenboom, in print), which inhabits interstitial and cave water of NE Italy, Yugoslavia, and Rumania. It is characterized by a stout body with long coxae but shortened distal parts of appendages, with the exception of very long and slender pereiopod dactyli. In some characters, including the rostrum development and shape of basal antennal articles, the group is extremely diverse.

* Biological Institute, P.O. Box 40, YU 81000 Titograd, Yugoslavia

** Biology Department, Biotechnical Faculty, Aškerčeva 12, YU 61000 Ljubljana, Yugoslavia 
Niphargus numerus sp. n. (Figs. 1-4)

Material examined

1 male (holotype), cave Čavlinska pećina near Obrovac, Croatia.

\section{Description}

Holotype male, $3.7 \mathrm{~mm}$. Body stout. Head with a short rostrum, lateral lobes slightly elongated, subrounded, slightly exceeding half of the first peduncular article of antenna I. Metasomites I-III with about 4 short posterior marginal setae. Epimeral plates elongated and produced ventroposteriorly, angular; epimeron II with 1 submarginal spine anteriorly. Urosome low, urosomite I with a strong spine at the uropod base, I-II on each side with 1-2 spines, urosomite III smooth.

Telson long, exceeding half of uropod III, incised nearly to its base; each lobe has 4 distal spines and a pair of short plumose setae near the middle.

Antenna I almost reaching half of body-length, peduncular articles normal, progressively shorter and thinner, article 1 slightly longer than 2 and 3 together. Flagellum of 7 articles, most with a long aesthetasc each. Accessory flagellum obviously 1-articulated (second article indistinct), reaching less than half of first flagellar article.

Antenna II, peduncular article 3 short, articles 4-5 subequal, poorly setose. Flagellum of 5 articles, shorter than peduncle. Antennal gland cone exceeding the tip of peduncular article 3 . lobes.

Labrum entire, subrounded. Labium with well developed inner

Mandibular molar triturative. Left mandible with 5-dentate incisor accompanied by 7 spines (rakers) and by 4 -toothed lacinia mobilis. Right incisor 4-dentate, accompanied by a bifurcate and 6 dentate lacinia mobilis and with 6 spines. Palp's article 2 with 5-6 setae; article 3 nearly as long as article 2, with 8 marginal D- and 4 long distal E-setae, on its outer face with 1 group of $2 \mathrm{~A}$-setae, on inner tace with 2 single B-setae.

Maxilla I, inner plate with 2 distal setae. Outer lobe with 7-8 spines bearing lateral teeth (3-4 spines with 1 tooth, 1-4 spines with 2 teeth, 1-2 spines with 3 teeth). Palp reaching the distolateral corner of outer lobe, with 3-4 distal setae. Maxilla II, inner lobe without an oblique row of setae, both lobes with distomarginal setae only.

Maxilliped, inner lobe nearly reaching the distolateral tip of the first palp article, with 3 distal spines. Outer lobe reaching nearly $2 / 3$ of second palp article, bearing a row of distomedial spines. Palp article 4 with well developed nail.

Coxae I-IV much longer than wide, each with 3-4 distal setae, coxa IV not lobed. Coxa V remarkably shorter than IV but much wider, its posterior lobe wider but equally long as the anterior one. Coxa VI much smaller than $\mathrm{V}$, its posterior lobe much wider and longer than anterior one. Coxa VII small, semicircular. Coxal gills ovoid. 


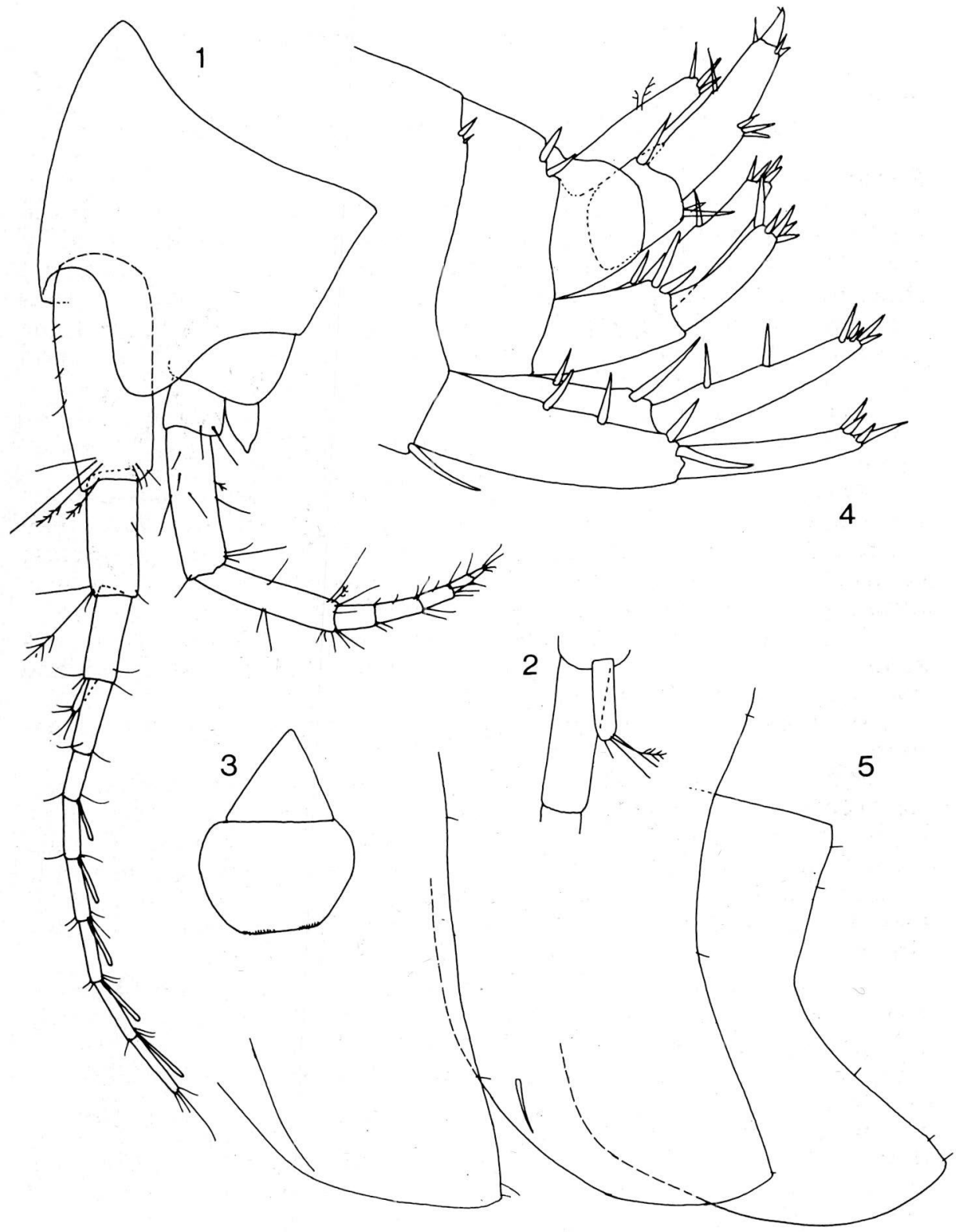

Fig. 1 - Niphargus numerus sp. n., Ćavlinska pećina, holotype $\delta 3.7 \mathrm{~mm}$ : 1 - head with antennae; 2 - accessory flagellum; 3 - labrum; 4 - urosoma with uropods and telson; 5 epimera I-III. 


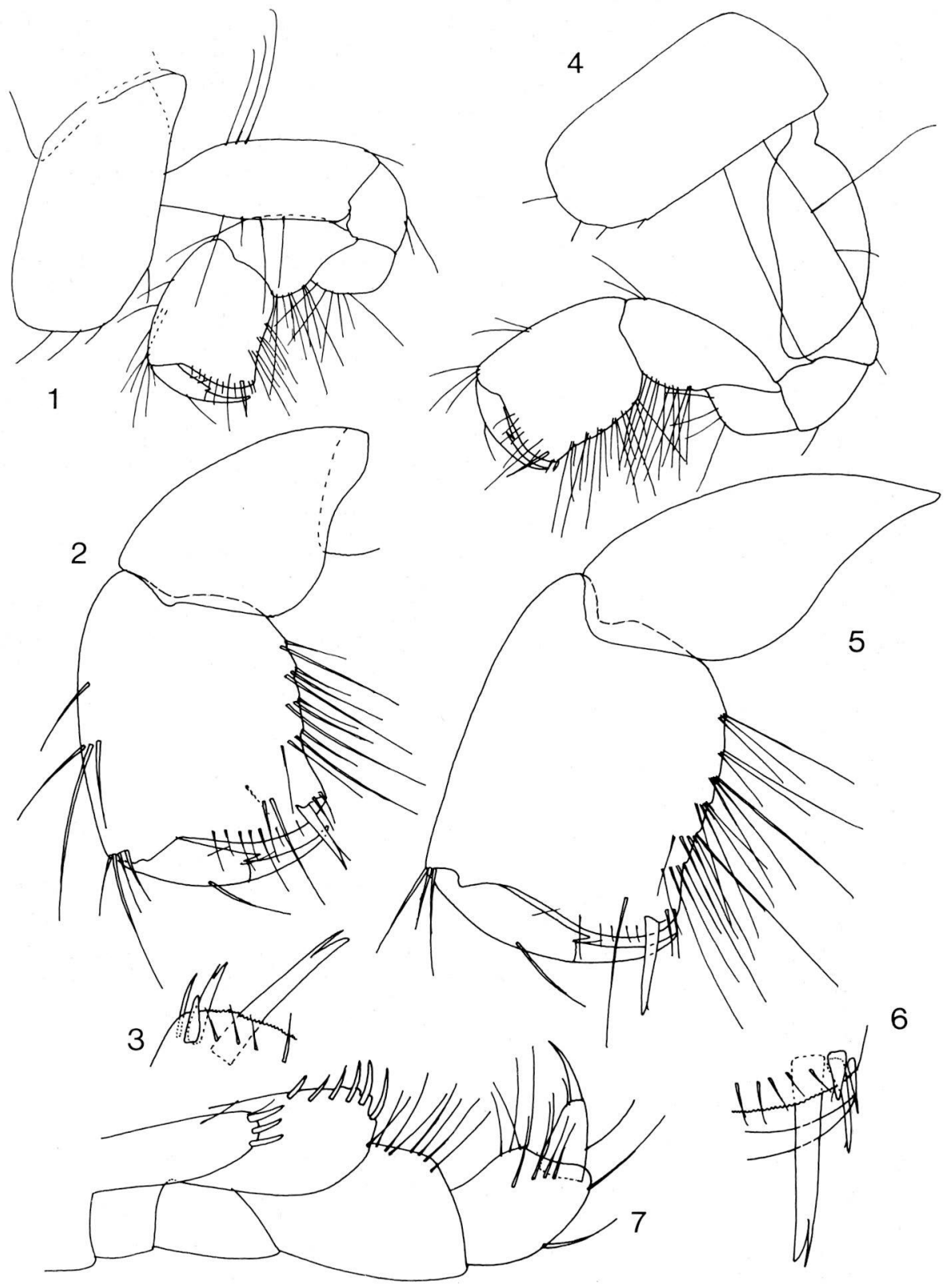

Fig. 2 -Niphargus numerus sp. n., Čavlinska pećina, holotype $\delta 3.7 \mathrm{~mm}: 1-3$ - gnathopod I; 4-6 - gnathopod II; 7 - maxilliped. 
Gnathopods I-II of kochianus-type, I slightly smaller than II. Article 6 much smaller than corresponding coxa, with subparallel margins, slightly longer than wide, with slightly produced distoposterior corner; palm transverse and bow-shaped, finely crenellated. Article 5 nearly as long as 6 . Dactylus reaching the distoposterior angle of article 6 , with 1 seta on its anterior face. Palmar angle I with a short inner spine and with 2 unequal slender outer spines and one spine-like seta, accompanied by 2 facial setae. Palmar angle II similarly armed, but with only 1 facial seta.

Pereiopods III-IV subequal, article 6 longer than 5; dactyl only slightly shorter than article 6 , without inner spine or seta, nail longer than socle.

Pereiopods V-VII short and stout, VII slightly shorter than preceding ones (ratio V:VI:VII $=104: 108: 100$ ). Article 2 large, ovoid and lobed, bearing about 7 posterior marginal setae and 7-10 anterior marginal spines; anterior margin arched, in pereiopod $\mathrm{V}$ distally produced in a lobe. Articles 3-6 progressively longer. Dactyl slender and long, but slightly shorter than article 6 , with $1-2$ very small inner setae, nail nearly as long as the socle.

Pleopods with 2 retinacula each. Peduncle of pleopod III distoposteriorly with a subdistal seta and a long, distal spine.

Uropods I-II short and stout, inner ramus longer than outer, with short lateral and distal spines; outer ramus with short distal spines only. Uropod III short; peduncle with 2 very strong distal spines; exopodite short, articulation between its articles indistinct; endopodite scale-like.

\section{Distribution and ecology}

Only 1 specimen of the new species was found in the cave Čavlinska pecina near Obrovac (ENE of Zadar), in the right edges of Zrmanja valley. Čavlinska pecina is a periodical outlet cave conducting waters from Ličko polje. Beside this specimen, only a specimen of Niphargus kolombatovici S. Karaman and some empty gastropod shells were found in pools of residual water along the long cave corridor. One can not exclude the possibility, that $N$. numerus inhabits also caves or even interstitial waters of Ličko polje.

\section{Taxonomical position}

$N$. numerus is most closely related to $N$. brevirostris Sket. Only 2 specimens of the latter were found in interstitial waters of the Gacko polje, which is situated NW of the above mentioned Ličko polje. Both species agree in many characters, including a number of apomorphies: development of an anterodistal lobe on the basipodite of pereiopod $\mathrm{V}$, very short flagellum of antenna $I$, anterior coxae more than twice as long as wide, and a distinctly developed rostrum. Autapomorphies of $N$. numerus are the uniarticulate accessory flagellum of antenna I, more 


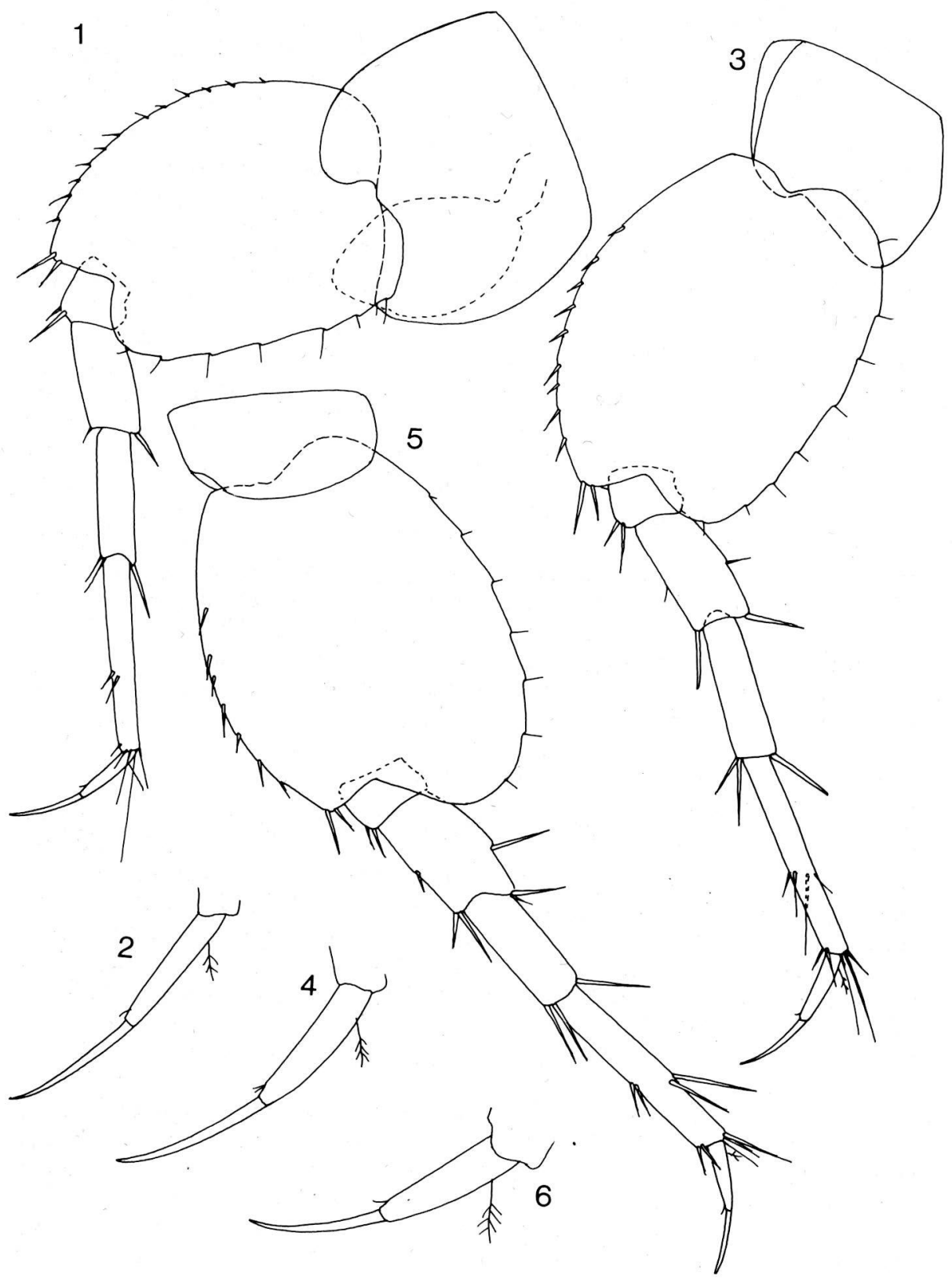

Fig. 3 -Niphargus numerus sp. n., Ćavlinska pećina, holotype o $3.7 \mathrm{~mm}: 1-2$ - pereiopod V; 3-4 - pereiopod VI; 5-6 - pereiopod VII. 


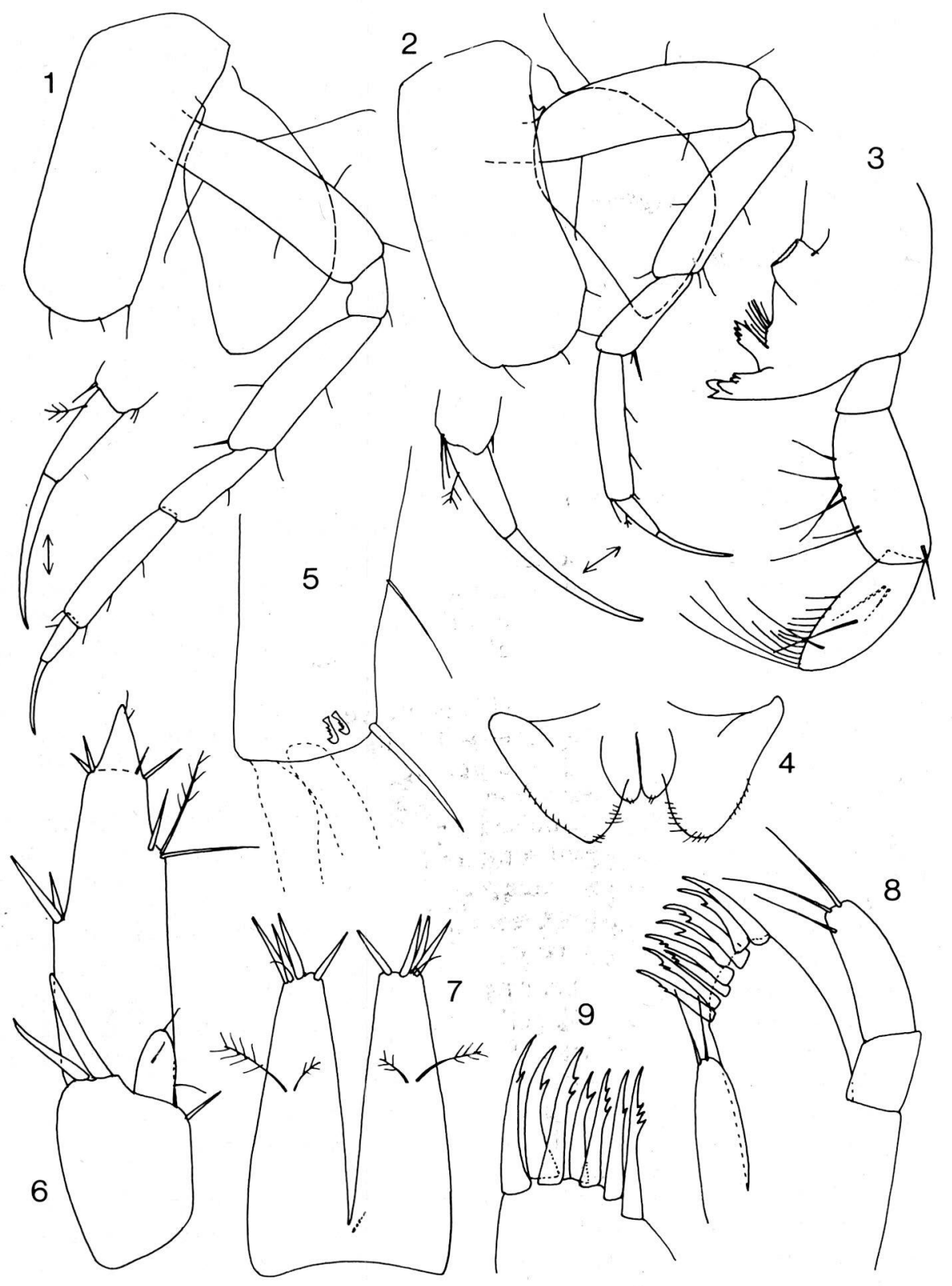

Fig. 4 -Niphargus numerus sp. n., Čavlinska pećina, holotype $ठ \$ 3.7 \mathrm{~mm}: 1-2$ - pereiopods III-IV; 3 - mandibula; 4 - labium; 5 - pleopod III; 6 - uropod III; 7 - telson; 8-9 - left and right maxilla $I$. 
shortened articles 4-6 of posterior pereiopods, particularly weakly developed inner seta on pereiods dactyli. An important differentiating character state may also be 2 outer setae on gnathopod dactyli in $N$. brevirostris. However, it is easily possible that both taxa are in fact only subspecifically differentiated, particularly as their possible variability is completely unknown.

\section{Niphargus factor sp. n. (Fig. 5-9)}

\section{Material examined}

5 specimens (incl. holotype), cave Vjetrenica (lakelet above the corridor Donja Vjetrenica), Zavala in Popovo polje, Hercegovina, September 1975.

? 2 juvenile specimens (their inclusion in the species is uncertain) cave Baba, Strujići in Popovo polje, Hercegovina, September 1975.

\section{Description}

Holotype female, with oostegites, $3 \mathrm{~mm}$. Body stout. Head dorsally remarkably arched in lateral projection. Rostrum well developed, lateral lobes slightly produced, rounded-triangular. Mesosomites smooth; metasomites with 2 setae each on their dorsoposterior margins. Urosomite I with a spine at the uropod basis and with 1 dorsal spine, urosomite II with 2 dorsal spines on each side, urosomite III smooth.

Epimeral plates produced, with acute ventroposterior angles and straight posterior margins. Epimeron II with 1 and epimeron III with 2 long, submarginal spines in their anteroventral parts.

Telson very long, twice as long as sympodite of uropod III, much longer than wide and deeply incised. Lobes narrow, each with 3 slender distal spines and 0-1 marginal seta; a pair of (unequally) long plumose setae appears in distal part of each lobe.

Antenna I only slightly exceeding half of the body length. Peduncle stout, articles 1-3 progressively shorter and thinner, all poorly setose. Flagellum with 11 articles bearing 1 aesthetasc each, they are nearly as long as articles. Accessory flagellum shorter than peduncular article 3 , but as long as or longer than flagellar article 1; it is 1-2 articulated (article 2 distinctly or indistinctly separated).

Antenna II, peduncular article 3 short, articles 4-5 subequal,poorly setose. Flagellum stout, of 4 articles, slightly shorter than last peduncular article. Antennal gland cone short.

Labrum distally rounded, labium with well developed inner lobes.

Left mandible with 4-dentate lacinia mobilis and 5-dentate incisor, accompanied by 8 spines. Right mandible with 4-dentate incisor, lacinia mobilis divided in 2 unequal lobes, pluridentate and accompanied by 6 spines. Palpus moderately developed, article 2 with 9 marginal and 2 inner facial setae; article 3 slightlty shorter than 2 , with 3 single B-setae, one group of $3 \mathrm{~A}$-setae, about $11 \mathrm{D}$ - and 5 long, distal E-setae. 


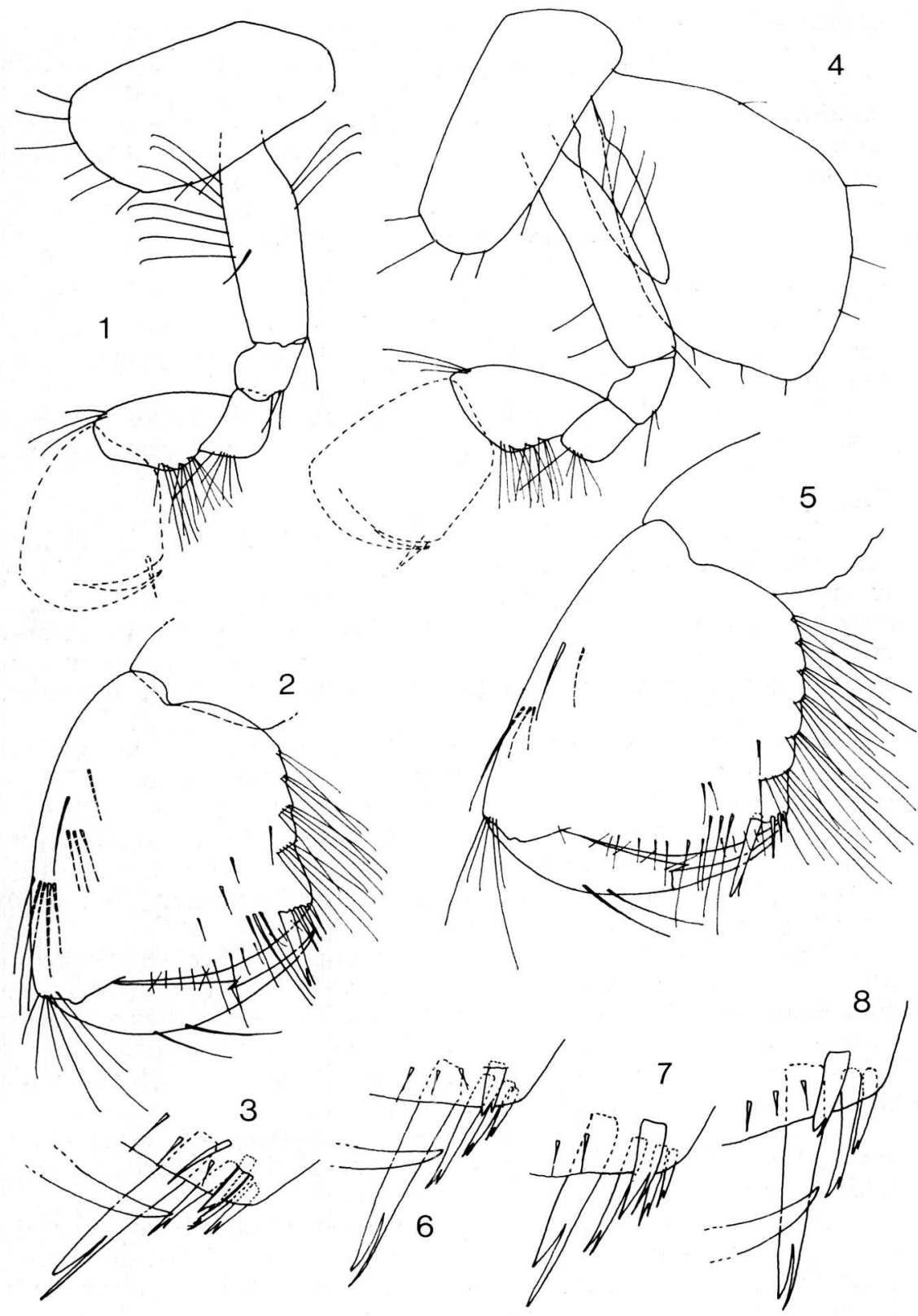

Fig. 5 - Niphargus factor sp. n., Vjetrenica, holotype $\$ 3 \mathrm{~mm}$ : 1-3 - gnathopod I; 4-6 gnathopod II. ơ $3 \mathrm{~mm}$; 7-8 - gnathopods I-II. 


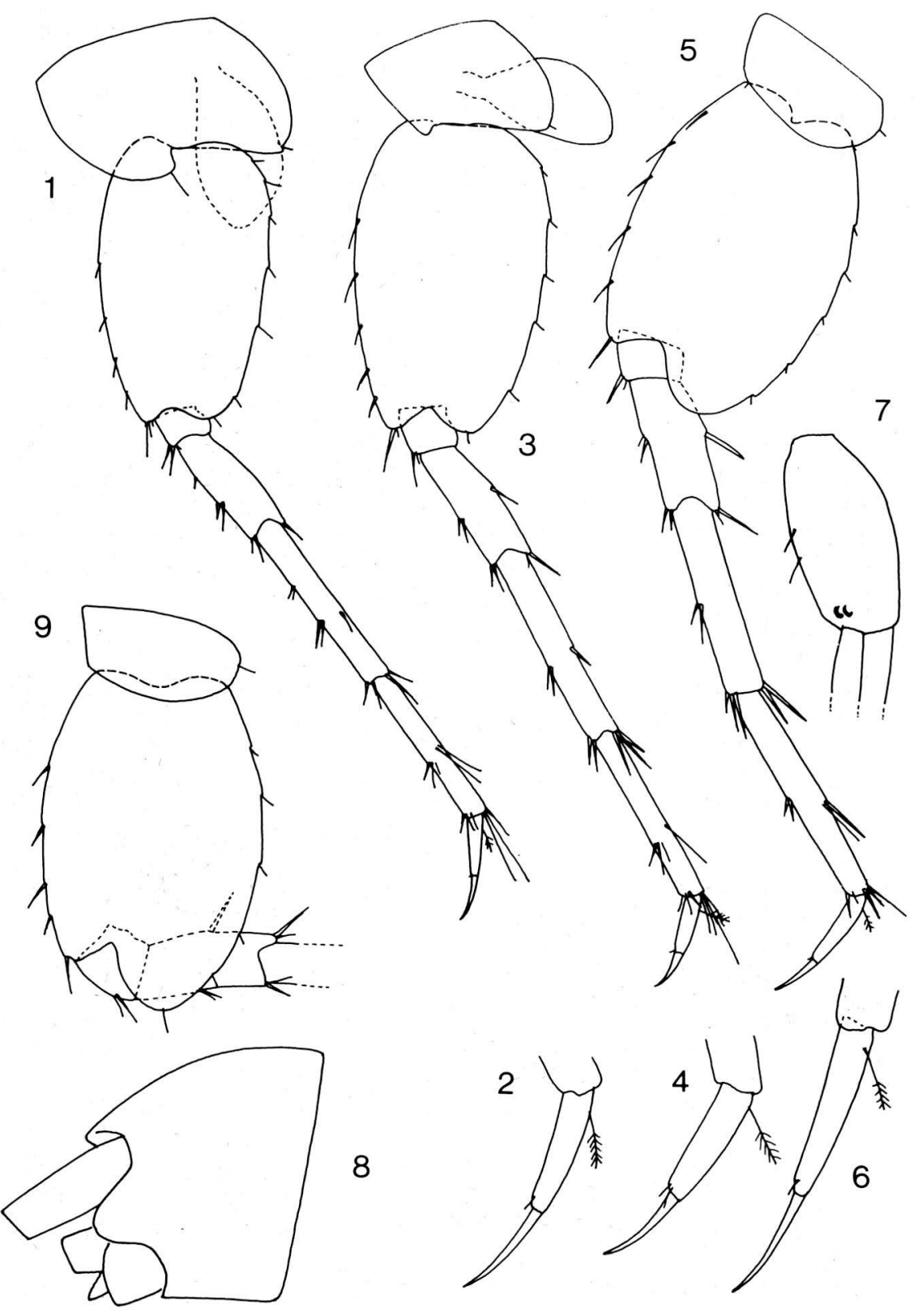

Fig. 6 - Niphargus factor sp. n., Vjetrenica, holotype $93 \mathrm{~mm}$ : 1-2 - pereiopod V; 3-4 pereiopod VI; 5-6 - pereiopod VII; 7 - pleopod III; 8 - head. $\delta 3 \mathrm{~mm}$ : 9 - pereiopod VII. 
Maxilla I, inner lobe with 1-2 apical setae. Outer lobe with 7 spines; innermost spine always with 4 lateral teeth, others unidentate or 2 of them bidentate. Palpus reaching beyond the base of spines, with 6 distal setae. Maxilla II with both lobes only marginally setose.

Maxilliped, inner lobe short, with 3 short distal spines; outer lobe reaching nearly the middle of palp article 2 , at its inner and distal margins with a row of smooth spines. Palp article 4 with nail shorter than socle, with 3 setae in the ventrodistal part of the socle.

Coxae I-IV much longer than wide, with semicircular apical margins bearing 4-6 long setae, IV without a lobe. Coxae V-VI with small anterior and very large posterior lobe; coxa VII shallow, entire. Coxal gills on pereionites II-VI, ovoid, with narrow peduncles. Oostegites wide, with marginal setae.

Gnathopods I-II relatively small. Articles 3-4 with a group of setae each on their posterior margins. Article 6 longer than wide, slightly widened towards distal part; palma arched and slightly oblique, finely crenellated. Palmar angle on outer face with 3 facial setae and 1 strong corner spine, accompanied posteriorly by 3 slender bicuspidate spines; a short subcorner spine on the inner face. Dactylus hardly reaching posterior margin of article 6 , with 2 setae along its outer face. In gnathopod I, article 5 is slightly shorter than 6 , in gnathopod II, they are nearly equally long; all parts of gnathopod II are slightly larger.

Pereiopods III-IV slender; dactylus long, only slightly shorter than article 6, with nail as long as socle; with a poorly visible inner seta.

Pereiopods V-VII relatively short, only slightly progressively longer, in ratio 100:103:105 (all articles measured). Article 2 in pereiopod V narrowly ovate, VI-VII progressively wider and with stronger distoposterior lobe; only 6-7 posterior marginal setae. Articles 4-6 slender and progressively longer. Dactyli slender, slightly longer than half of article 6, nail shorter than socle; with a small inner seta and a plumose proximal outer seta.

Pleopods with short and stout peduncles bearing 2 retinacula each. Posterior face of peduncle III with 2 setae.

Uropod I, peduncle dorsoexternally with 1 facial and 2 strong distal spines; dorsointernal row represented only by 1 distal spine. Inner ramus distinctly longer than outer one, each of them with 1 lateral and some short distal spines. Uropod II smaller, but similarly built and armed as I.

Uropod III very short and stout. Peduncle only slightly longer than wide. Endopodite scale-like, with 1 distal seta. Exopodite cone-shaped; proximal article with 2-3 groups of 1-2 spines along its outer margin, and with a group of 2 spines and 1 plumose seta on its inner margin; distal article short with distal setae only.

\section{Variability}

Male, $3 \mathrm{~mm}$ long, is very similar to female regarding antennae, coxae, gnathopods, other pereiopods, uropods, and telson. Gnathopod 


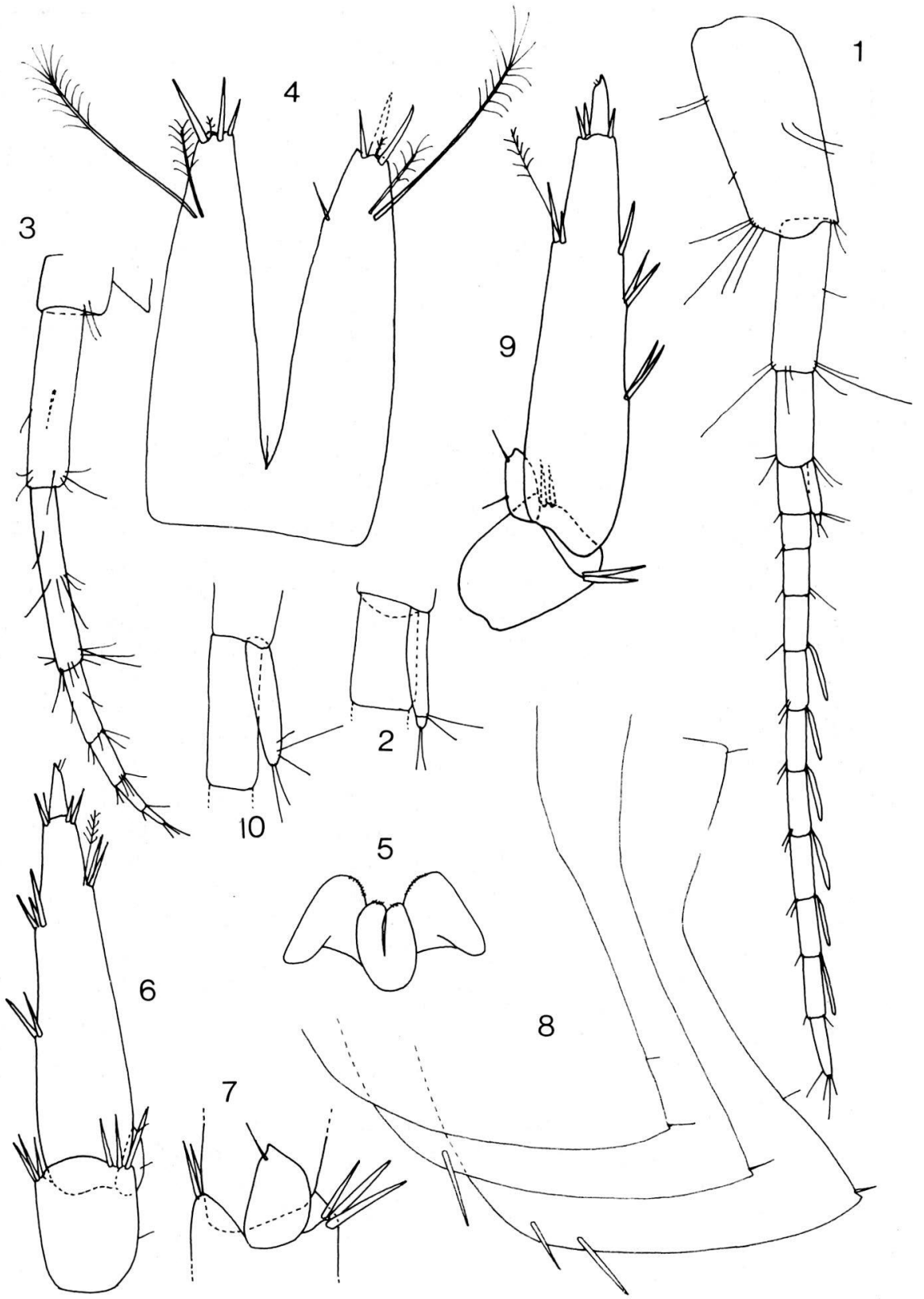

Fig. 7 - Niphargus factor sp. n., Vjetrenica, holotype $\$ \mathrm{~mm}$ : 1-2 - antenna I; 3 - antenna II; 4 - telson; 5 - labium; 6-7 - uropod III; 8 - epimera I-III. ơ 3 mm: 9 - uropod III; 10 accessory flagellum. 


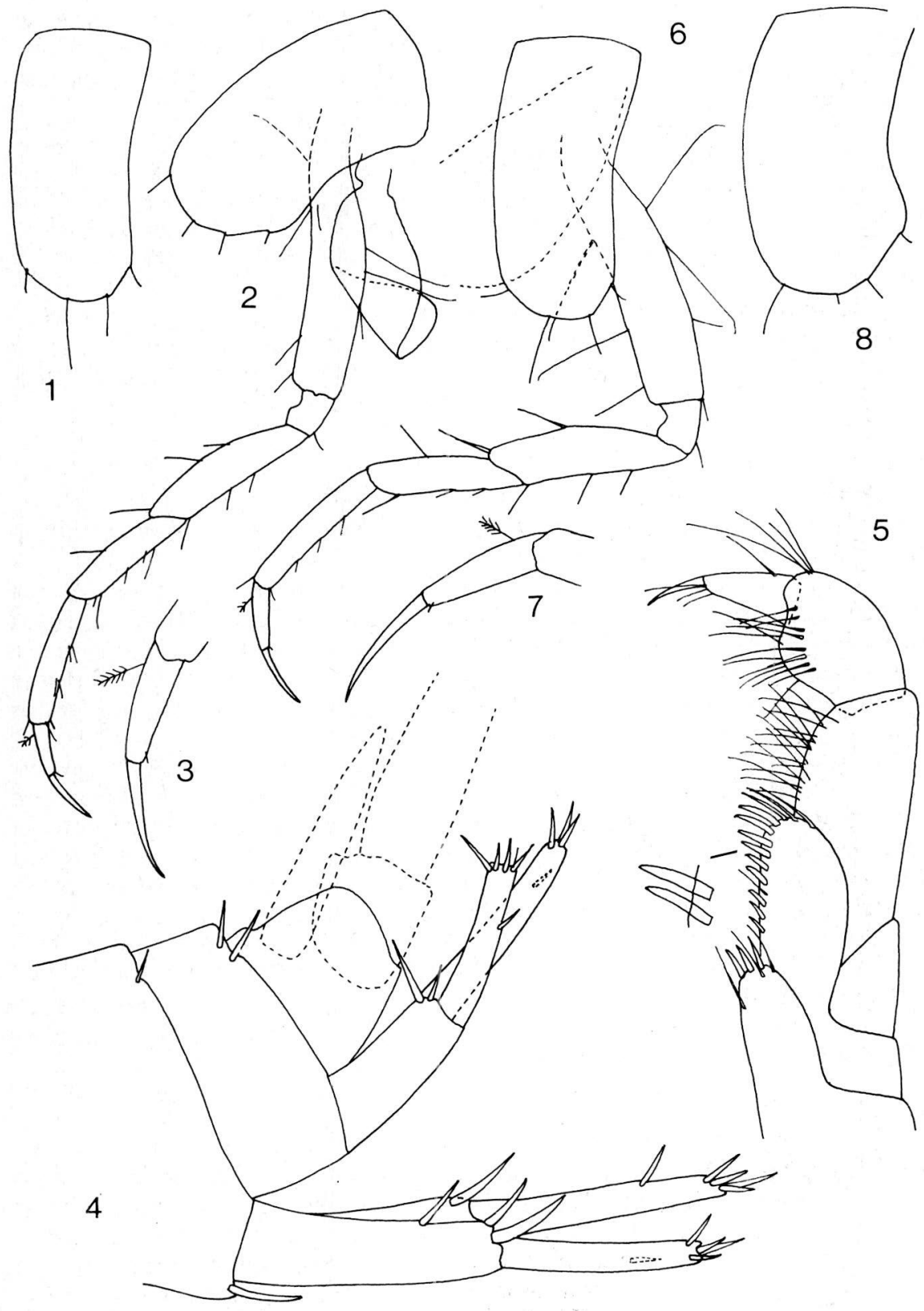

Fig. 8 - Niphargus factor sp. n., Vjetrenica, holotype $\$ 3 \mathrm{~mm}$ : 1 - coxa III; 2-3 - pereiopod IV; 4 -urosoma with uropods I-II; 5 - maxilliped. ơ 3 mm: 6-7 - pereiopod III; 8 - coxa IV. 
II, palmar spine accompanied by only 2 bicuspidate spines. Urosomites I-II with single dorsolateral spines. Antennal flagellum I with 9 articles, accessory flagellum uniarticulated. Flagellum II of 5 articles. Epimera II-III with 1 submarginal spine each.

In all specimens, accessory flagellum may be either 1 - or 2 articulated, with distal article always very small. Peduncle of pleopod III with 1-2 posterior setae. Urosomite II with 1-2 dorsoposterior spines on each side. Tip of the uropod III endopodite obtuse or nearly pointed. Smaller specimens of ca. $2 \mathrm{~mm}$ often with only 1 outer seta on gnathopod dactyli.

The specimens from the cave Baba are only ca. $2 \mathrm{~mm}$ long; they mostly agree with the above description but their pereiopod dactyli III-VII are shorter; antennal accessory flagellum is 2-articulated. Richer material is needed to identify this population with certainty.

\section{Distribution and ecology}

Both localities of the new species are caves situated in the karstic borders of Popovo polje in Hercegovina. It is one of the speleobiologically richest regions in Yugoslavia and in the world.

In September 1975, 10 specimens collected in the main corridor of the cave Vjetrenica at Zavala, in a lakelet fed by percolation water, at the entrance to the corridor called Donja Vjetrenica (Lower Vjetrenica). In this lakelet with clay and stone at the bottom, enriched with some rotten wood, $N$. factor was accompanied by a very rich population of Hadzia fragilis fragilis S. Karaman as well as by single specimens of $N$. kolombatovici S. Karaman, Microcharon sp., Acanthocyclops venustus (Norm. \& Scott), and Oligochaeta. Single specimens were found at the beginning of the Absolon Channel, accompanied by single specimens of other crustaceans and by a very rich population of the gastropod Iglica absoloni (A.J. Wagner) and some sparser Orientalina troglobia (Bole). The temperature of the above mentioned waters was $11-12^{\circ} \mathrm{C}$.

In the periodical outlet cave Baba pećina near Strujići, two specimens of probably the same species were found in residual pools with temperatures of $12-13^{\circ} \mathrm{C}$. They were accompanied by a very diverse but quantitatively poor crustacean fauna ( 8 additional species) and some Gastropoda and Nematoda.

\section{Taxonomical position}

$N$. factor is most closely related to $N$. asper G. Karaman from a well near Titograd. They share all of their probable synapomorphies also with the above mentioned two taxa, which are however much more apomorph; therefore the similarity may also originate in convergent evolution. These two taxa also exhibit an anterolobate basipodite of pereiopod V, very long anterior coxae, a reduced number of spine groups along the uropod III. $N$. factor exhibits more autapomorphies than its counterpart; its coxa IV is completely non-lobate (it is slightly dilated in its distal part in N. asper), its posterior pereiopod dactyli are 

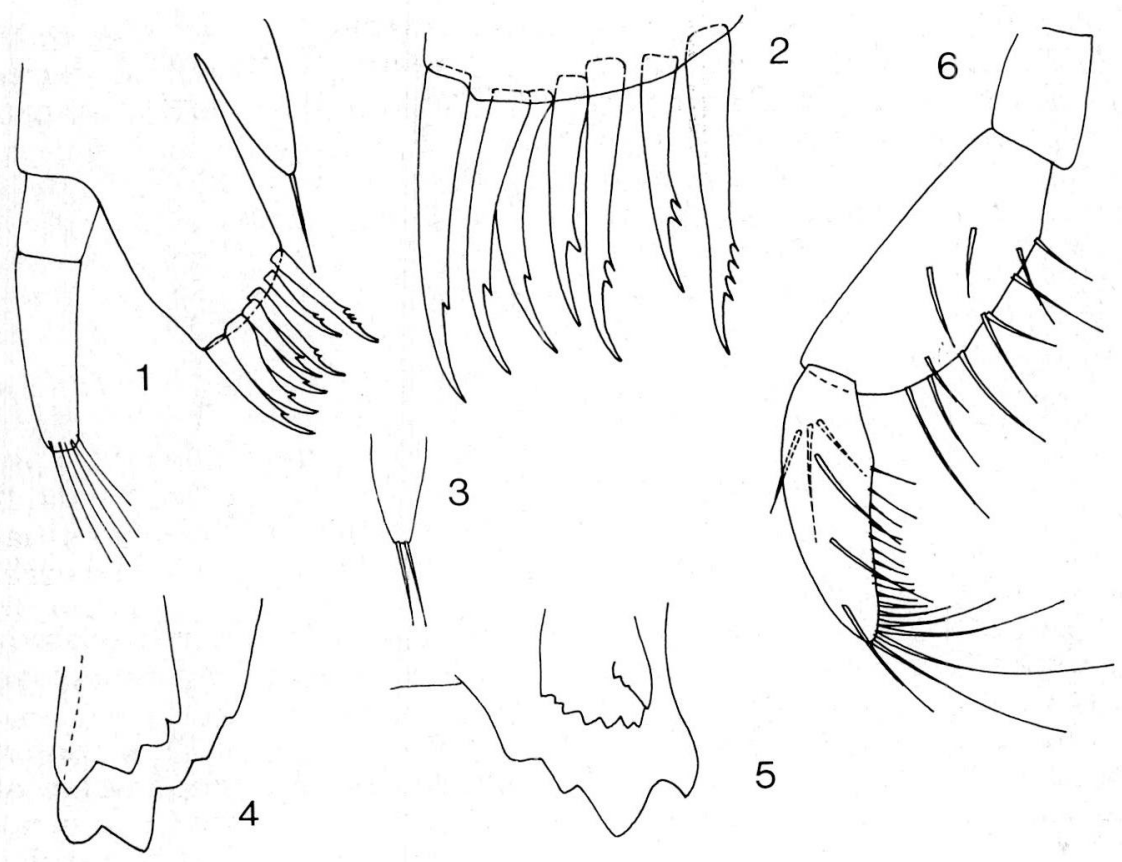

5
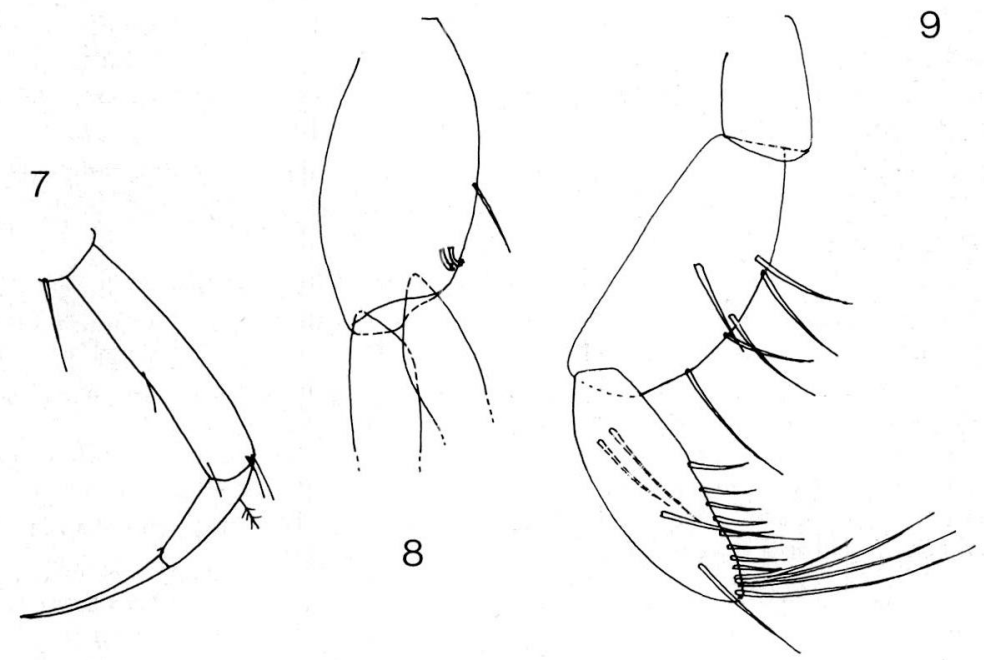

Fig. 9 -Niphargus factor sp. n., Vjetrenica, holotype $\$ 3 \mathrm{~mm}$ : 1 - right maxilla I; 2 - left maxilla I; 3 -inner lobe of maxilla I of another specimen); 4-5 - pars incisiva of left and right mandibula; 6 - palpus mandibularis. $\$ 2.1 \mathrm{~mm}: 7$ - pereiopod IV; 8 - pleopod III; 9 palpus mandibularis. 
longer and slender, they are armed only with inner seta (spine in $N$. asper), rostrum is developed, article 3 of palpus mandibularis is shortened. Plesiomorphic or indefinable differentiating character states of the new species are the more oblique gnathopod palma, basipodites of posterior pereiopods are narrower and with less convex anterior margins, the lateral cephalic lobes are less produced.

\section{CONCLUSIONS}

With the both new taxa, Niphargus numerus sp. n. and N. factor sp. $\mathrm{n}$., the number of taxa in the $N$. transitivus aggregate reaches 12 . Six of them inhabit hypogean waters of the Dinarid Region while others are distributed in plains north of it, from NE Italy to central Roumania. It is interesting to note that populations of some of the interstitial non-karstic taxa tend to be denser in dug out wells (cf. Sket et Velkovrh, 1981). Similarly, the Dinaric species occur in caves as well as in interstitial waters of karst poljes. Since $N$. numerus and $N$. brevirostris have till now been found in only a few specimens, it is difficult to make inferences about their preferred habitat. It seems likely that this aberrant members of the genus, are - probably owing to their special ethology (vertical posture) - ecologically successful in a number of different hypogean habitats.

\section{REFERENCES}

KARAMAN, G.S. 1974. Crustacea Amphipoda. Catalogus Faunae Jugoslaviae III/3 Acad. Sci. Art. slovenica, Ljubljana $44 \mathrm{pp}$.

KARAMAN, G.S. 1983. A survey of investigations of freshwater Amphipoda (Crustacea, Malacostraca) in Yuguslavia, with bibliography (Contribution to the knowledge of the Amphipoda 123). Glas republ. Zavoda Zast. Prirode - Prir. Muz. Titograd 16: 97-116.

SKET, B. 1971. Vier neue aberrante Niphargus-Arten (Amphipoda. Gammaridae) und einige Bemerkungen zur Taxonomie der Niphargus-ähntichen Gruppen. Razprave Dissertationes, Cl. IV, 14 (1): 1-27.

SKET, B. and J. NOTENBOOM. (in print). Definition and analysis of the Niphargus transitivus aggregate of species (Crustacea: Amphipoda) and its distribution.

SKET, B. and F. VELKOVRH. 1981. Phreatische Fauna in Ljubljansko polje (LjubljanaEbene, Jugoslavien) - ihre ökologische Verteilung und zoogeographische Beziehungen (Phreatic Fauna of the Ljubljana Field / Yugoslavia / - its ecological distribution and zoogeographical connections). Int. J. Speleol. 11: 105-121. 